\title{
GERABAH SITUS MANSINAM KAJIAN ETNOARKEOLOGI
}

\author{
Klementin Fairyo \\ (Balai Arkeologi Jayapura)
}

\begin{abstract}
The Process of vessels making in Mansinam site was not far too different with other places in Indonesia: using clay as the basic material. The vessel making was a woman's work, started from clay gathering to firing process. Based on the observation of the edge shape, it is predicted that the vessels found in Mansinam Island belongs to the type of pot. The observation on the core shows that on the process of making, the firing was opened and not spread evenly. Pot was used for cooking and keeping food. The vessels from Mansinan Island has spread vast through trade and barter to Wandamen coastal area, Biak Numfor islands, Bird's Head Peninsula coastal areas and Raja Ampat Islands.
\end{abstract}

Keywords: Mansinam sites, vessels making, vessel function

\section{Pendahuluan}

Pulau Mansinam memiliki potensi yang strategis pada masa lalu. Wilayah ini juga diperkirakan sejak abad ke-16 merupakan bagian dari jalur dagang antara Indonesia bagian barat dan Papua. Hal ini terbukti dengan temuan tempayan dan keramik Vietnam serta sejumlah temuan pecahan gerabah di sepanjang pantai Pulau Mansinam (Tim Penelitian, 2009: 34).

Temuan pecahan gerabah yang terdapat di Papua dapat diketahui dari hasil penelitian arkeologi tersebut bahwa pemakaian gerabah di kalangan masyarakat Papua pada umumnya ditemukan di daerah pesisir dan tersimpan di dalam gua-gua. Gerabah Situs Mansinam dibuat oleh orang Numfor yang bermigrasi ke tempat ini jauh sebelum para missionaris pertama dari Eropa mendarat di pulau ini pada 5 Februari 1855.

Hasil-hasil gerabah dari Pulau Mansinan menyebar luas melalui perdagangan dalam bentuk barter ke daerah pesisir Wandamen, ke Kepulauan Biak Numfor dan ke daerah-daerah pesisir pantai Kepala Burung sampai kepada Kepulauan Raja Ampat. Begitu terkenalnya hasil periuk dari Mansinam sehingga di daerah Biak, periuk-periuk tanah dari Mansinam dinamakan uren doreh (uren; belanga; doreh; teluk), nama teluk dimana Pulau Mansinam terletak. 


\section{Pembahasan}

a. Gerabah Situs Mansinam sebagai bukti pemukiman di Pulau Mansinam sebelum abad ke-19.

Pemukiman di Pulau Mansinam hingga abad ke-19 berada di sepanjang pesisir pantai. Penduduk tinggal di rumah panggung di atas air. Berdasarkan hasil wawancara dengan kepala Desa Mansinam Daniel Rumbrawer (wawancara, 20 Maret 2009), rumah panggung ini disebut rumah berlabuh (rumberlab). Bahan rumah ini kayu suan, daun nipa, dan pelepah nipa.

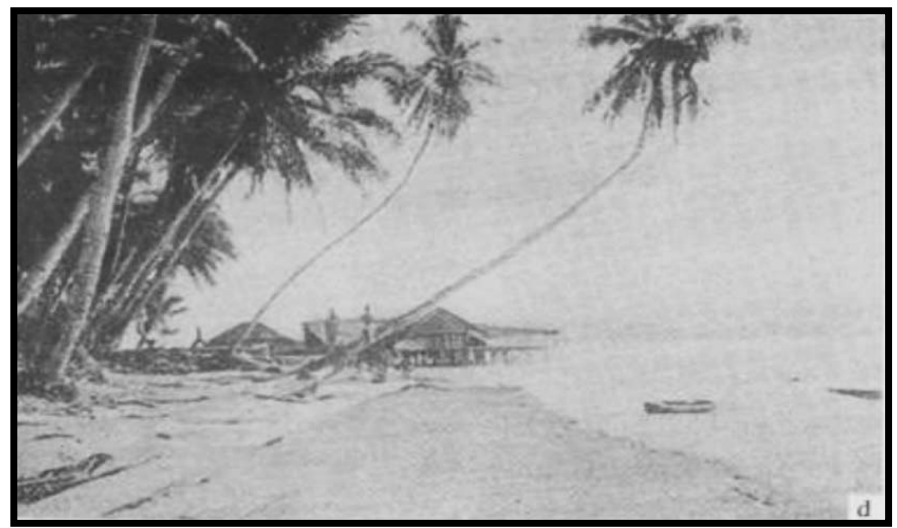

Rumah Berlabuh di Pulau Mansinam Sumber: F.C. Kamma, 1982

Bukti-bukti pemukiman rumah berlabuh ini adalah sisa-sisa pondasi kayu dan di sepanjang pantai ditemukan pecahan-pecahan gerabah, pecahan tempayan dan pecahan keramik. Pecahan gerabah ini berjenis periuk. Periuk-periuk ini dipergunakan untuk memasak dan menyimpan makanan. Motif hias yang terdapat pada pecahan gerabah di Pulau Mansinam, berupa lukisan dengan teknik tera. Motif ini termasuk dalam seni Saireri (Yapen Waropen, Wandamen, dan Biak Numfor). Motif yang diterapkan pada gerabah di Mansinam, diperkirakan dibawa oleh orang Numfor yang bermigrasi ke Mansinam.

Berdasarkan pengamatan di Pulau Mansinam terdapat deposit tanah liat, maka diperkirakan gerabah yang ditemukan dilokasi penelitian dibuat di Pulau Mansinam. Hal ini didukung informasi (Daniel Rumbrawer, wawancara 20 Maret 2009) bahwa di Mansinam pernah ada pembuatan gerabah yaitu keluarga Rumbobiar. 
b. Pembuatan Gerabah Tradisional

Berdasarkan hasil wawancara dengan Kepala Desa Mansinam (Daniel Rumbrawer, wawancara 20 Maret 2009), secara tradisional bahan dasar pembuatan gerabah diMansinam adalah tanah liat. Bahan tanah liat ini dinamakan saprop uren (saprop= tanah; uren=belanga) yang diambil dari daerah Kwawi. Pembuatan periuk tanah adalah merupakan pekerjaan wanita mulai dari pengumpulan tanah sampai kepada pembakaran. Kaum laki-laki hanya membantu membuat hiasan-hiasan pada papan berhias (ai bebaser befeyek) yang kemudian akan dicetak pada bagian luar periuk atau tempayan kalau dibutuhkan.

Teknik pembuatan gerabah ini melalui beberapa tahap yaitu tanah liat dan pasir hitam disebarkan di atas tikar yang dibentangkan pada tanah rata kemudian di siram dengan air tawar atau air asin lalu diinjak-injak dengan kaki. Pada saat ini kotoran-kotoran berupa batu, sisa kayu yang tercampur dengan bahan di bersihkan. Bahan yang sudah tercampur itu digulungkan dalam bentuk bulat yang cukup untuk pembuatan sesuatu benda tertentu yang diinginkan kemudian dibuatkan ruang atau lubang di dalam bulatan tanah tersebut dengan bantuan sebuah batu berbentuk bulat panjang disebut keru beso selanjutnya dengan batu bulat lain yang licin dihaluskan bagian dalam belanga sedangkan luarnya dihaluskan dengan papan berbentuk dayung kecil. Apabila pembuat gerabah ingin memberikan hiasan pada benda yang dibuat maka dengan papan berhias di cetaklah hiasan-hiasan. Setelah itu benda dijemur selama kurang lebih setengah hari. Tahap pengerjaan berikut ialah pembakaran, benda-benda yang sudah dijemur (biasanya dalam jumlah banyak) diatur di atas tumpukan kayu bakar kemudian ditutup dengan daun kelapa atau daun sagu, lalu di atasnya tertimbun lagi kayu bakar, setelah itu dibakar. Apabila pembakaran sudah selesai maka periuk sudah siap untuk dipakai tetapi sebelumnya dibersihkan dengan cara mendidihkan air panas kedalamnya terlebih dulu.

\section{c. Temuan Gerabah Situs Mansinam}

Gerabah yang ditemukan dalam penelitian di wilayah Mansinam berupa pecahan-pecahan yang terdiri atas bagian tepian, badan polos dan badan hias. Pecahan gerabah ini ditemukan di sepanjang pantai Pulau Mansinam. Berdasarkan pengamatan terhadap bentuk tepian, maka diperkirakan gerabah yang ditemukan di Pulau Mansinam berjenis periuk. Wadah jenis ini berfungsi untuk memasak dan menyimpan makanan. 
Fragmen tepian periuk

Dok. Balar Jayapura 2009

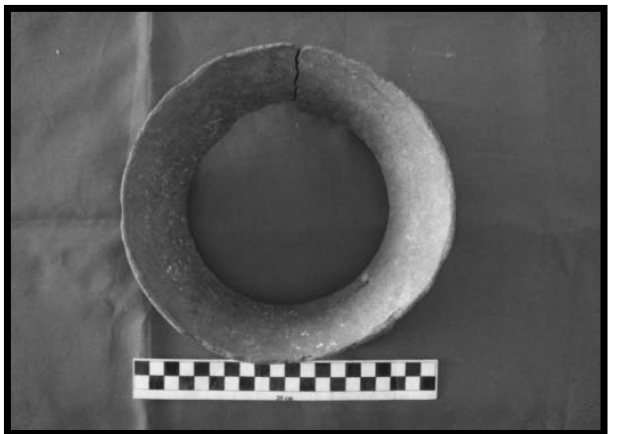

Berdasarkan pengamatan terhadap temuan gerabah di situs Mansinam maka teknik pembuatan gerabah ini memakai teknik roda putar dan tatap, teknik tatap terlihat pada cekungan-cekungan pada dinding bagian dalam gerabah. Teknik roda putar terlihat pada adanya striasi pada dinding gerabah bagian luar. Pengamatan terhadap penampang lintang (core) gerabah ini, maka menunjukkan pembakaran terbuka dan tidak merata. Pembakaran tidak sempurna juga dapat dilihat pada kondisi gerabah yang mudah rapuh sewaktu dipegang. Pola hias yang terdapat pada gerabah ini diantaranya motif karerin dan motif garis. Motif karerin dibuat dengan teknik tera. Motif karerin merupakan motif hias yang dimiliki oleh masyarakat penghuni pulaupulau di sekitar Teluk Cenderawasih (Yapen, Biak, Numfor). Sedangkan motif garis dibuat dengan teknik gores (Tim penelitian 2009).

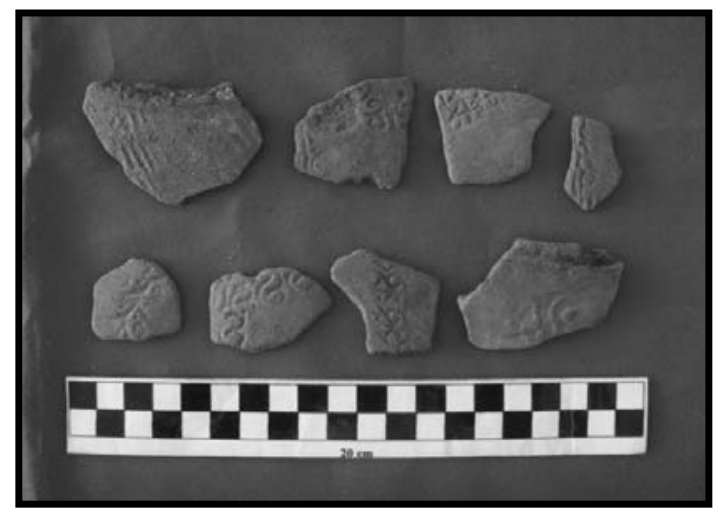

Fragmen Bagian badan dengan hias motif karerin (Dok. Balai arkeologi Jayapura 2009)

Pembuatan gerabah di situs Mansinam saat ini sudah tidak ditemukan lagi. Berdasarkan kajian etnoarkeologi yang dilakukan Hari Suroto (2004) terhadap pengrajin gerabah di Trenggalek, Jawa Timur, diketahui bahwa faktor penyebab perajin 
gerabah tidak mau memproduksi gerabah lagi, karena persaingan dengan peralatan dari plastik dan aluminium. Berbagai peralatan sehari-hari orang akan memilih bahan plastik yang dirasakan lebih praktis serta awet dengan harga yang relative dapat di jangkau. Realitas ini sepenuhnya dipahami jika suatu jenis gerabah tidak laku di pasaran, lambat laun jenis gerabah tersebut akan hilang (tidak diproduksi lagi), maka apabila hal ini terjadi terus menerus sampai turun ke generasi berikutnya, dengan sendirinya teknik pembuatannya akan ikut menghilang. Lebih dari itu arkeologi akan kehilangan bahan perbandingan. Dengan kata lain industri kerajinan gerabah tradisional ini juga merupakan suaka terhadap warisan budaya bangsa.

\section{Kesimpulan}

Pembuat gerabah di Pulau Mansinam adalah orang-orang Numfor yang bermigrasi ke Mansinam. Bahan baku pembuatan gerabah adalah tanah liat yang didapatkan dari Pulau Mansinam. Pembuatan gerabah dilakukan oleh perempuan. Pembakaran gerabah dilakukan secara terbuka di luar ruangan (open fire). Gerabah yang dihasilkan di Mansinam pada umumnya berbentuk periuk yang dalam fungsinya digunakan sebagai wadah untuk memasak dan menyimpan makanan. 


\section{Daftar Pustaka}

Hutagol, Luksan. 2000. Laporan Penelitian Sampel Pembuatan Gerabah Kampung Abar. Desa Atabar Kecamatan Sentani Kabupaten Jayapura. Balai Arkeologi Jayapura.

Suroto, Hari. 2004. Gerabah Situs Panggul (Analisis bentuk, teknik pembuatan dan fungsi). Skripsi. Denpasar: Jurusan Arkeologi Fakultas Sastra Universitas Udayana.

Tim Peneliti, 2009. Laporan Penelitian Arkeologi Kolonial Pulau Mansinam. Balai Arkeologi Jayapura.

Warami, 2009. Mansinam Situs Sejarah Peradaban Orang Papua. Makalah pada kegiatan Seminar Arkeologi Jayapura. 


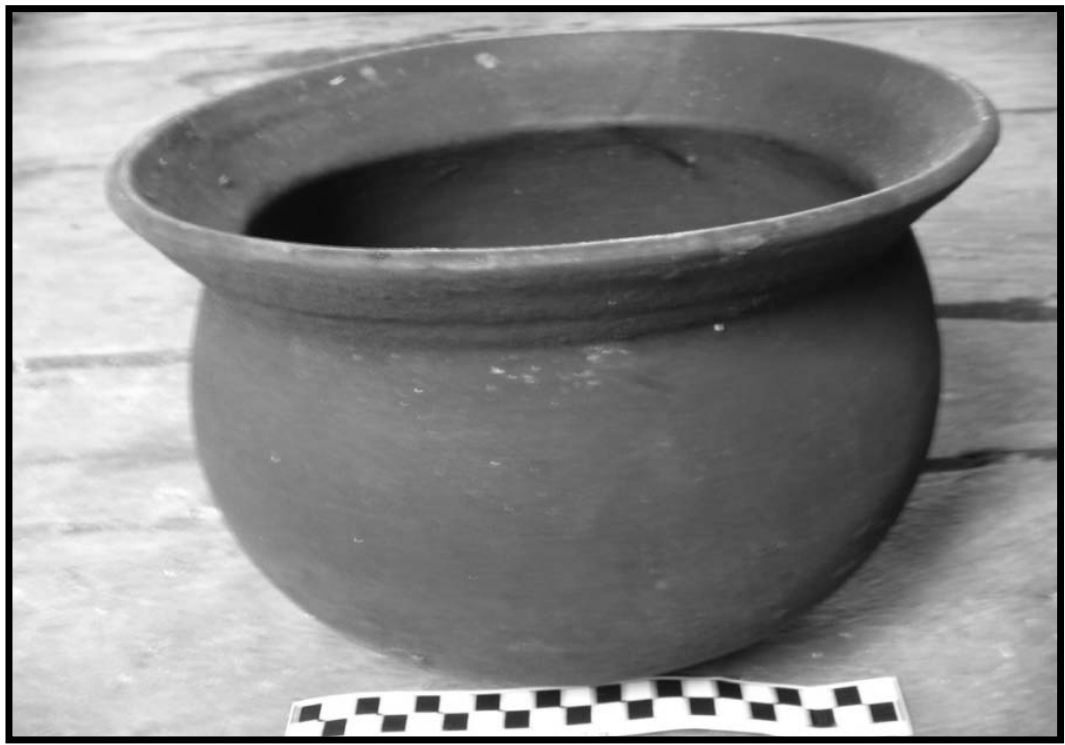

Periuk yang didatangkan ke Pulau Arefi, Raja Ampat, oleh pedagang dari luar 